\title{
Physiological Variations in Cucurbita moschata Duch. Ex. Poir Due to a Nigerian Strain of Moroccan Watermelon Virus: Lagenaria breviflora Isolate
}

\author{
A. A. J. Mofunanya ${ }^{1^{*}}$, E. A. Effa ${ }^{1}$, D. O. Etim ${ }^{1}$, F. A. Akomaye ${ }^{1}$ and A. O. Damian ${ }^{1}$ \\ ${ }^{1}$ Department of Botany, Faculty of Biological Sciences, University of Calabar, Calabar, Nigeria.
}

Authors' contributions

This work was carried out in collaboration among all authors. Author AAJM designed the study, wrote the protocol, and wrote the first draft of the manuscript. Authors EAE and DOE managed the analyses of the study. Author FAA performed the statistical analysis, author AOD managed the literature searches All authors read and approved the final manuscript.

Article Information

DOI: 10.9734/ARRB/2021/v36i830407 Editor(s):

(1) Dr. Bechan Sharma, University of Allahabad, India.

Reviewers:

(1) Hamit Ayberk, Istanbul University-Cerrahpasa, Turkey. (2) Andriani Rafael, Artha Wacana Christian University, Indonesia. Complete Peer review History: https://www.sdiarticle4.com/review-history/72275

Original Research Article

Received 24 May 2021

Accepted 31 July 2021 Published 02 August 2021

\begin{abstract}
Aim: Physiological variations in Cucurbita moschata due to infection with a Nigerian strain of Moroccan watermelon virus (MWMV): Lagenaria breviflora isolate was studied.

Study Design: Randomized block design was used.

Place and Duration of Study: Botany Department, University of Calabar, Calabar, Nigeria between March and May, 2015.

Methodology: Seeds of C. moschata were sown, on germination inoculated with the virus and analyzed for possible variations between healthy and inoculated plants.

Results: Results analysis revealed increase in all amino acids investigated. Highest significant $(\mathrm{P}=0.05)$ percentage variation in amino acids of inoculated and healthy were $-40.0 \%$ for aspartic acid, $-36.1 \%$ (histidine), $-29.7 \%$ (proline), $-28.8 \%$ (lysine), $-23.3 \%$ (glysine), $-16.6 \%$ (phenylalanine) and $-12.6 \%$ (glutamic acid). Infection of C. moschata with a Nigerian Strain of MWMV: Lagenaria breviflora isolate caused significant decrease in leaf nitrogen and relative water content of inoculated plants compared to the healthy. Highest percentage decrease in leaf nitrogen was $40.7 \%$ at 2 weeks after inoculation (WAI) and lowest of $25.0 \%$ at $10 \mathrm{WAl}$. The virus caused
\end{abstract}


decrease in relative water content of $29.6 \%$ at 6 WAl. Activity of oxidative stress enzymes: peroxidase (POD) and polyphenol oxidase (PPO) and enzymes of the oxidative pentose phosphate pathway: glucose-6-phosphate dehydrogenase (6PGdH) and 6-phosphogluconic acid dehydrogenase $(\mathrm{G} 6 \mathrm{PdH})$ were significantly $(\mathrm{P}=0.05)$ increased in infected $C$. moschata- MWMV plant. Enzymes activity was significantly higher in inoculated than in healthy plants at all stages of growth with decrease at later periods for both inoculated and healthy plants. Percentage increase in POD, PPO, G6PdH and 6PGdH activity due to infection at 8 WAl had values of $-40.5 \%,-46.7 \%$, $-98.9 \%$ and $-89.1 \%$ respectively.

Conclusion: The Nigerian strain of MWMV: Lagenaria breviflora isolate caused significant variations with increase and decrease in biochemical and physiological components of $C$. moschata affecting its growth and yield.

Keywords: Cucurbita moschata; amino acids; enzymes activity; leaf nitrogen; Moroccan watermelon mosaic virus; relative water content.

\section{INTRODUCTION}

Cucurbita moschata (Duch ex. Poir) (family: Cucurbitaceae) is an important annual dicotyledonous crop, with creeping or climbing stems bearing tendrils. It is cultivated as a vegetable crop for its leaves and fruits in the southern parts of Nigeria, where it also act as effective cover against soil erosion and competes favorably with weeds. Attack on cucurbits by viruses affects basic physiological processes creating an imbalance in components. Variations in plants physiological and biochemical components caused by plant viruses are the underlying factors for poor crop yield. Virus infection of plants is accompanied by variations in cellular metabolism of host plants with effects on whole plant functioning. Plant viruses are among the most destructive pathogens, responsible for damages on most agronomically important crops, with loses estimated at tens of billions U.S. dollars annually [1], which might increase since viruses constitute the largest cohort of emerging crop diseases [2].

The production of cucurbits worldwide is limited by several viruses. Moroccan watermelon mosaic virus (MWMV) strain is one of the viruses reported on C. moschata. It is a Potyvirus (family: Potyviridae) causing severe damage to cucurbits with symptoms in susceptible plant of mosaic, leaf malformation and green banding [3]. Previous studies focused on strains of Moroccan watermelon mosaic virus isolated from Lagenaria breviflorus and Coccinia barteri [4], Changes in growth, chlorophyll, phytochemicals, proximate, minerals and antinutrients of $C$. moschata due to a Nigerian strain of MWMV were studied [5]. To appreciate these changes, the present study was conducted to examine variations in some physiological and biochemical components between healthy and C. moschata inoculated with MWMV: L. breviflora isolate. Variations in components such as amino acids, relative water content, leaf nitrogen content and enzymes activity between healthy and inoculated $C$. moschata plants were investigated to explain poor growth caused by MWMV infection.

\section{MATERIALS AND METHODS}

\subsection{Planting Materials}

Seeds of C. moschata were purchase from a farmer at the University of Calabar Staff Quarters whose plants were monitored on the field for symptoms expression. Two seeds were sown in each polyethylene bag filled with steam-sterilized soil. The work was carried out in the Botanic Garden greenhouse of the Department of Botany, University of Calabar, Nigeria with average temperature of $25 \pm 3^{\circ} \mathrm{C}$. The seeds germinated six days after planting and the seedlings staked to enhance performance.

\subsection{Inoculum Preparation and Plant Inoculation}

A Nigerian strain of Moroccan watermelon mosaic virus: Lagenaria breviflorus isolate used in this study was maintained in L. breviflorus. Young symptomatic leaves were collected, ground in a sterilized mortar and pestle in disodium phosphate buffer $0.03 \mathrm{M}, \mathrm{pH}$ 8.0. The inoculum obtained was applied on C. moschata seedlings dusted with carborundum (800-mesh) at two-leaf stage mechanically by leaf-rub. The inoculated leaves were rinsed with water and observed for symptom development under greenhouse condition of $25 \pm 3^{\circ} \mathrm{C}$. Prior to 
inoculation, plants to be inoculated and those of the control were arranged in a randomized block design (RBD) with a total of 60 plants. Thirty plants were inoculated with the virus and the other thirty plants were inoculated with the buffer only to serve as control. Cucurbita moschata inoculated with MWMV were left for symptom development such as mosaic, leaf malformation and green banding typical of MWMV infection.

\subsection{Determination of Variation in Amino Acids Content Due to MWMV}

At eight weeks after inoculation, inoculated and healthy leaves of C. moschata were harvested, shade-dried, pulverized and used for amino acids analysis. This was conducted by methods described by [6]. About $0.8 \mathrm{~g}$ of dried sample was weighed into an extraction thimble and the fat was extracted with chloroform/method (2:1) mixture using an extraction apparatus as described by [7]. The extraction lasted for $15 \mathrm{~h}$. A known weight of the defatted sample was weighed into glass ampoule to which $7 \mathrm{ml}$ of $6 \mathrm{~N}$ $\mathrm{HCl}$ was added and oxygen expelled by passing nitrogen into the ampoule. The glass ampoule was then sealed with Burnsen burner flame and put in an oven preset at $105^{\circ} \mathrm{C} \pm 5^{\circ} \mathrm{C}$ for $22 \mathrm{~h}$. The ampoule was allowed to cool before its tip was broken open and the content filtered to remove the humins.

The filtrate was evaporated to dryness at $40^{\circ} \mathrm{C}$ under vacuum in a rotary evaporator. The residue was dissolved in $5 \mathrm{ml}$ acetate buffer $(\mathrm{pH}$ 2.0) and stored in plastic specimen bottles, which were kept in the freezer. Ten $\mu \mathrm{m}$ of the solution was dispensed into the Technicon Sequential Multi-samples Amino Acid Analyzer (TSM) to separate and analyze the free acidic, neutral and basic amino acids of the hydrolysate and the period of the analysis lasted $76 \mathrm{~min}$.

The chart recorder of the TSM produced the chromogram peaks (each representing an amino acid) from which the value for each amino acid was measured. The half-height of the peak on the chart was measured and width on the halfheight was accurately measured and recorded. Approximate area of each peak was obtained by multiplying the height with the width at halfheight.

The norleucine equivalent (NE) for each amino acid in the standard mixture was calculated using the formula:
$\mathrm{NE}=\frac{\text { Area of norleucine peak }}{\text { Area of each amino acid }}$

A constant $\mathrm{S}$ was calculated for each amino acid in the standard mixture:

$\mathrm{S}_{\text {std }}=\mathrm{NE}_{\text {std }} \times$ mol. Weight and $\mu \mathrm{MAA}_{\text {std }}$

The amount of each amino acid present in inoculated and healthy samples of $C$. moshata were calculated in $\mathrm{g} / 14 \mathrm{~N}$ or $\mathrm{g} / 100 \mathrm{~g}$ protein using the following formula:

Concentration (g/100 g protein) = NH x W@HN/2 $\mathrm{xS}_{\text {std }} \times \mathrm{C}$

Where:

$\mathrm{C}=\frac{\text { Dilution } \times 16}{\text { Sample } 16 \text { (g) } \mathrm{N} \% 10 \times \text { vol. Loaded }} \times \mathrm{NH} \times \mathrm{W}$ (nleu)

$\mathrm{NH}=$ Net height

$\mathrm{W}=$ Width 2 half height

Nleu $=$ Norleucine

\subsection{Relative Water Content and Leaf Nitrogen Content Determination}

Variation in relative water content between healthy and C. moschata inoculated with a Nigerian strain of MWMV was determined at 2, 4, 6,8 and 10 WAl by the method of [8]. Ten leaf pieces of $2 \mathrm{~cm}$ diameter were cut from healthy and inoculated plants and weighed immediately to obtain their fresh weight (FW). Turgid weight (TW) was measured by weighing the leaf segments after $24 \mathrm{~h}$ of immersion in distilled water in a sealed flask at room temperature. Dry weight (DW) measurement was carried out by weighing leaf segments after $48 \mathrm{~h}$ at $70^{\circ} \mathrm{C}$ in an oven and the RWC of leaves calculated and expressed as a percentage. Variation in leaf nitrogen content between healthy and virus inoculated plants was determination using standard Kjeldahl techniques.

\subsection{Enzymes Determination}

\subsubsection{Enzyme extraction}

Enzyme extraction buffer comprised of $50 \mathrm{mM}$ mixed monobasic potassium phosphate salt $\left(\mathrm{KH}_{2} \mathrm{PO}_{4}\right), 50 \mathrm{nM}$ dibasic potassium phosphate $\left(\mathrm{K}_{2} \mathrm{HPO}_{4}\right)$, to this was added $4 \mathrm{~g}$ of polyvinyl polypyrrolidone (PVPP) a phenol absorbent. The mixture was thoroughly mixed with the aid of a magnetic stirrer and adjusted to final $\mathrm{pH}$ 7.0. 
Enzyme extraction was carried out at $4{ }^{\circ} \mathrm{C}$ with $0.2 \mathrm{~g}$ of MWMV inoculated and healthy leaf tissues of $C$. moschata harvested randomly from experimental plots at different periods of growth were homogenized in pre-chilled mortar and pestle in $10 \mathrm{ml}$ extraction buffer. The homogenate filtered through cheese cloth and the filtrate centrifuged at 4,000 rpm for 4 minutes. The supernatants for inoculated and healthy samples were stored in an ice chamber and used as crude enzyme sources in assaying POD and PPO.

\subsubsection{Enzyme assay}

Enzyme assay was conducted using a mixture of $50 \mathrm{mM}$ mixed monobasic potassium phosphate salt $\left(\mathrm{KH}_{2} \mathrm{PO}_{4}\right), 50 \mathrm{nM}$ dibasic potassium phosphate $\left(\mathrm{K}_{2} \mathrm{HPO}_{4}\right)$ and $\mathrm{pH}$ adjusted to 7.0. Readings were taken at appropriate wavelength for each enzyme with the aid of a spectrophotometer (Model 722S, England).

\subsubsection{Peroxidase assay (EC.1.11.17.7)}

To assay buffer of $2 \mathrm{ml}$ in a cuvette was added $0.1 \mathrm{ml}$ of $10 \mathrm{ml}$ guaiacol and $0.1 \mathrm{ml}$ enzyme preparation. The reaction was started with the addition of $0.1 \mathrm{ml}$ of $10 \mathrm{mM} \mathrm{H}_{2} \mathrm{O}_{2}$, making up the final assay volume of $2.3 \mathrm{ml}$. Absorbance readings were taken at $436 \mathrm{~nm}$ at 1 minute spectrophotometrically using the assay buffer as blank. The expressed POD activity was calculated using an extinction coefficient 6.39 $\mathrm{mMcm}^{-1}$ for guaiacol dehydrogenation product

\subsubsection{Polyphenol oxidase assay (EC.1.14.18.1)}

To a cuvette containing $2 \mathrm{ml}$ of assay buffer was added $0.1 \mathrm{ml}$ of $10 \mathrm{mM}$ dihydroxyphenylalamine (DOPA) and $0.1 \mathrm{ml}$ enzyme preparation. The reaction was initiated by adding $0.1 \mathrm{ml}$ of $10 \mathrm{mM}$ $\mathrm{H}_{2} \mathrm{O}_{2}$ in a final volume of $2.3 \mathrm{ml}$. The absorbance was taken at 1 minute spectrophotometrically at $470 \mathrm{~nm}$ [9]. The activity of PPO expressed was calculated using an extinction coefficient of 1433 $\mathrm{nMcm}^{-1}$.

\subsubsection{Glucose-6-phosphate dehydrogenase (G6PdH: EC1.1.1.44) and 6- phosphogluconic acid dehydrogenase (6PGdH: EC 1.1.1.49) assay}

These enzymes activities were conducted spectrophotometrically at $3^{\circ} \mathrm{C}$ following the reduction of NADP at $340 \mathrm{~nm}$. The assay mixtures consisted of $100 \mathrm{ml}$ triethanolamine hydrochloride- $\mathrm{NaOH}, 10 \mathrm{ml} \mathrm{MgCl} 2,10 \mathrm{ml} \mathrm{NADP}$, $10 \mathrm{ml}$ 6-phophogluconate or glucose-6phosphate and $5 \mathrm{ml}$ of crude enzyme extract at $\mathrm{pH}$ 7.5. To $2 \mathrm{ml}$ assay buffer contained in a cuvette was added $0.1 \mathrm{ml}$ of $0.8 \mathrm{mM} 6 \mathrm{PGdH}$ or $0.1 \mathrm{ml}$ of $0.83 \mathrm{mM} \mathrm{MgCl} 2, \mathrm{NADP}$ and $0.1 \mathrm{ml}$ crude enzyme extract added to start the reaction in a final volume of $2.4 \mathrm{ml}$ and readings taken spectrophotometrically at $430 \mathrm{~nm}$ for inoculated and healthy leaves samples of $C$. moschata for 4 min. All G6PdH activities were corrected for the possible complicating effect of $6 \mathrm{PGdH}$ on the G6PdH assay [10].

\subsection{Statistical Analysis}

Data obtained were analyzed using the independent t-Test statistics and the significant difference between inoculated and healthy plants. Results were also expressed as percentage difference and differences between mean values were determined at $5 \%$ probability.

\section{RESULTS}

\subsection{Variation in Amino Acid Profile of Cucurbita moschata Due to Infection with a Nigerian Strain of Moroccan Watermelon Virus: Lagenaria breviflora Isolate}

There was significant variation in amino acids content of inoculated $C$. moschata plants compared to the healthy. Healthy plants had lower amino acids than inoculated plants. Infection of $C$. moschata with MWMV: $L$. breviflora isolate caused significant $(P=0.05)$ increase in all amino acids. Inoculated $C$. moschata had the highest increase in histidine, followed by aspartic acid, lysine, glycine, phenylalanine and glutamic acid with mean percentage increase of $13.55 \pm 0.02,13.73 \pm 0.06$, $6.66 \pm 0.03,5.83 \pm 0.02$ and $4.56 \pm 0.01 \mathrm{~g} / 100$ protein respectively compared to healthy plant values of $9.61 \pm 0.01,12.19 \pm 0.01,5.17 \pm 0.01$, $4.73 \pm 0.02$ and $3.91 \pm 0.01 \mathrm{~g} / 100$ protein respectively (Fig. 1).

\subsection{Variation in Leaf Nitrogen Content and Relative Water Content of Cucurbita moschata Due to Infection with a Nigerian Strain of Moroccan Watermelon Virus: Lagenaria breviflora Isolate}

Variation in RWC of healthy and inoculated $C$. moschata showed significant $\quad(P=0.05)$ 
differences in content. Inoculated plants had lower RWC than the healthy. Insignificant variation in RWC was found at initial period (2 WAI) of growth with value of $42.14 \pm 1.00$ for inoculated and $43.56 \pm 1.13$ for healthy plants. However, significant variation in RWC occurred with prolonged infection. Moroccan watermelon mosaic virus caused significant percentage decrease in RWC of $57.61 \pm 0.04$ for inoculated C. moschata as against $80.67 \pm 1.10$ for healthy plants at $8 \mathrm{WAl}$ (Fig. 2A). Variation in leaf nitrogen content of $C$. moschata inoculated with MWMV was found. Inoculated and healthy plants had the highest leaf nitrogen content at 2 WAl. However, leaf nitrogen content decreased with increasing period of growth for healthy as well as inoculated plant samples. Mean percentage decrease in leaf- $\mathrm{N}$ of inoculated plant sample at 2 WAl was $41.61 \pm 0.01$ and $70.15 \pm 0.03$ for healthy plants. At $10 \mathrm{WAI}$ inoculated $C$. moschata had leaf nitrogen content of $29.19 \pm$ 0.02 and $38.91 \pm 0.03$ for the healthy plants samples (Fig. 2B).

\subsection{Variation in Peroxidase (POD), Polyphenol Oxidase (PPO), Glucose- 6-Phosphate Dehydrogenase (6PGdH), 6-Phosphogluconic Acid Dehydrogenase (G6PdH) Activity of Cucurbita moschata Due to Infection with a Nigerian Strain of Moroccan Watermelon Virus: Lagenaria breviflora Isolate}

Results as presented in Fig. 3A, 3B, 3C, and 3D revealed that MWMV: Lagenaria breviflora isolate caused $(P=0.05)$ increase in all enzymes studied. Inoculated plants had higher enzymes activity than the healthy. All enzymes activity increased from $2 \mathrm{WAI}$ to $8 \mathrm{WAl}$ and decreased at $10 \mathrm{WAI}$. Peroxidase activity at $8 \mathrm{WAI}$ varied with an increase of $5123.43 \pm 0.0001$ for inoculated and $364.68 \pm 0.003(\mathrm{u} / \mathrm{min} / \mathrm{mg}$ of protein) for healthy plants. At $10 \mathrm{WAl}$ enzyme activity varied with increase of $4819.19 \pm 0.0006$ for inoculated and $3112.88 \pm 0.006 \mathrm{u} / \mathrm{min} / \mathrm{mg}$ of protein for healthy plants (Fig. 3A). Polyphenol oxidase activity varied between inoculated and healthy plants of C. moschata. Variation at 2 WAI for inoculated and healthy was $15.56 \pm 0.0002$ and $10.89 \pm 0.0004 \mathrm{u} / \mathrm{min} / \mathrm{mg}$ of protein, $20.31 \pm$
0.0003 and $13.66 \pm 0.0004 \mathrm{u} / \mathrm{min} / \mathrm{mg}$ of protein at $8 \mathrm{WAl}, 18.75 \pm 0.0003$ and $13.52 \pm 0.0004$ $\mathrm{u} / \mathrm{min} / \mathrm{mg}$ of protein at $10 \mathrm{WAI}$. Polyphenol oxidase activity decreased at 10 WAI for both healthy and inoculated plants (Fig. 3B). Variation in enzyme activity of the oxidative pentose pathway G6PdH was found due to infection of $C$. moschata by MWMV. A similar trend of increase in enzyme activity at early period of growth and decrease at later period was found for both healthy and inoculated with activity of inoculated being higher when compared to the healthy. Activity of $\mathrm{G} 6 \mathrm{PdH}$ was higher in inoculated plants and lower in healthy ones. Activity at $8 \mathrm{WAI}$ for inoculated and healthy plants of $3.98 \pm 0.0033$ and $1.73 \pm 0.0033 \mu \mathrm{mol}$.NADPH formed $/ \mathrm{min}$ of protein (Fig. 3C). Moroccan watermelon mosaic virus significantly $(P=0.05)$ increased $6 \mathrm{PGdH}$ activity of inoculated $C$. moschata compared to the healthy. Variation in activity of $6 \mathrm{PGdH}$ in inoculated and healthy plant were $3.12 \pm 0.002$ and $1.65 \pm 0.0004 \mu \mathrm{mol}$.NADPH formed $/ \mathrm{min}$ of protein (Fig. 3D).

\section{DISCUSSION}

Physiological variations in C. moschata due to a Nigerian strain of MWMV: $L$. breviflora isolate was studied. The study elucidated variations between healthy and MWMV infected C. moschata in order to ascertain its effects on host plant physiology. The virus caused significant increase in amino acids content of $C$. moschata. Virus infection in plants has been associated with a plethora of biochemical and metabolic changes [11]. Variations occurred between amino acids of MWMV infected $C$. moschata which was higher in content than their healthy plants counter parts. This result is in agreement with report that Tomato yellow leaf curl virus infection of tomato plants significantly affected the mole percentage of free amino acids in phloem sap of tomato plants [12]. Increase in amino acids in this study could be attributed to increase in protein since amino acids are units of protein. In an earlier study, increase in protein was reported by [5] in $C$. moschata inoculated with a Nigerian strain of MWMV: L. breviflora isolate, in cotton plants infected with Cotton leaf curl virus (CLCuV) $[13,14]$. 


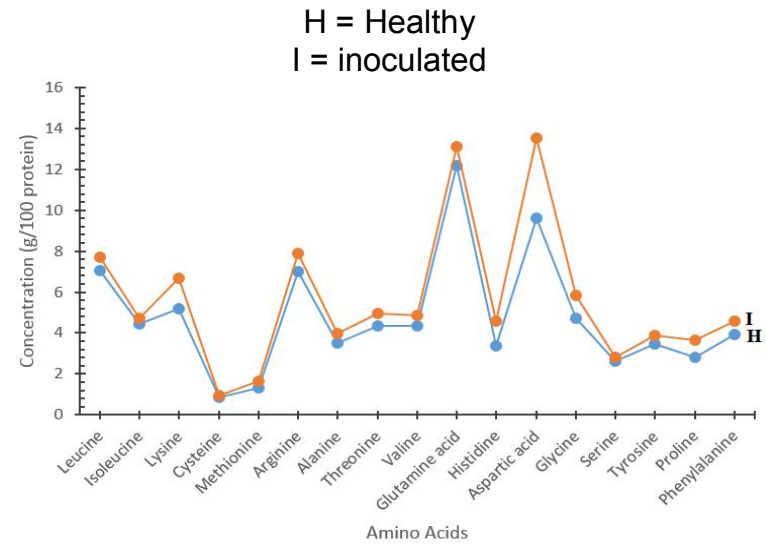

Fig. 1. Variation in amino acids profile of Cucurbita moschata due to infection with a Nigerian Strain of Moroccan watermelon virus: Lagenaria breviflora isolate
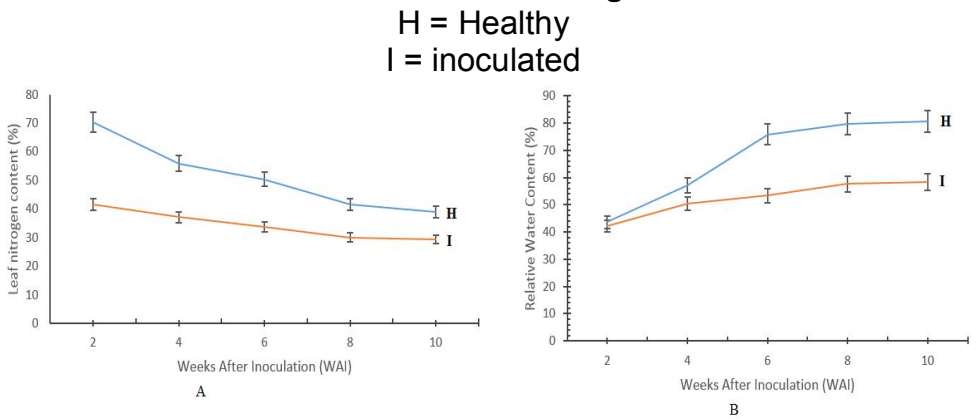

Fig. 2. Variation in $A=$ leaf nitrogen content and $B=$ relative water content of Cucurbita moschata due to infection with a Nigerian Strain of Moroccan watermelon virus: Lagenaria breviflora isolate

$$
\mathrm{H}=\text { Healthy }
$$

$\mathrm{I}=$ inoculated
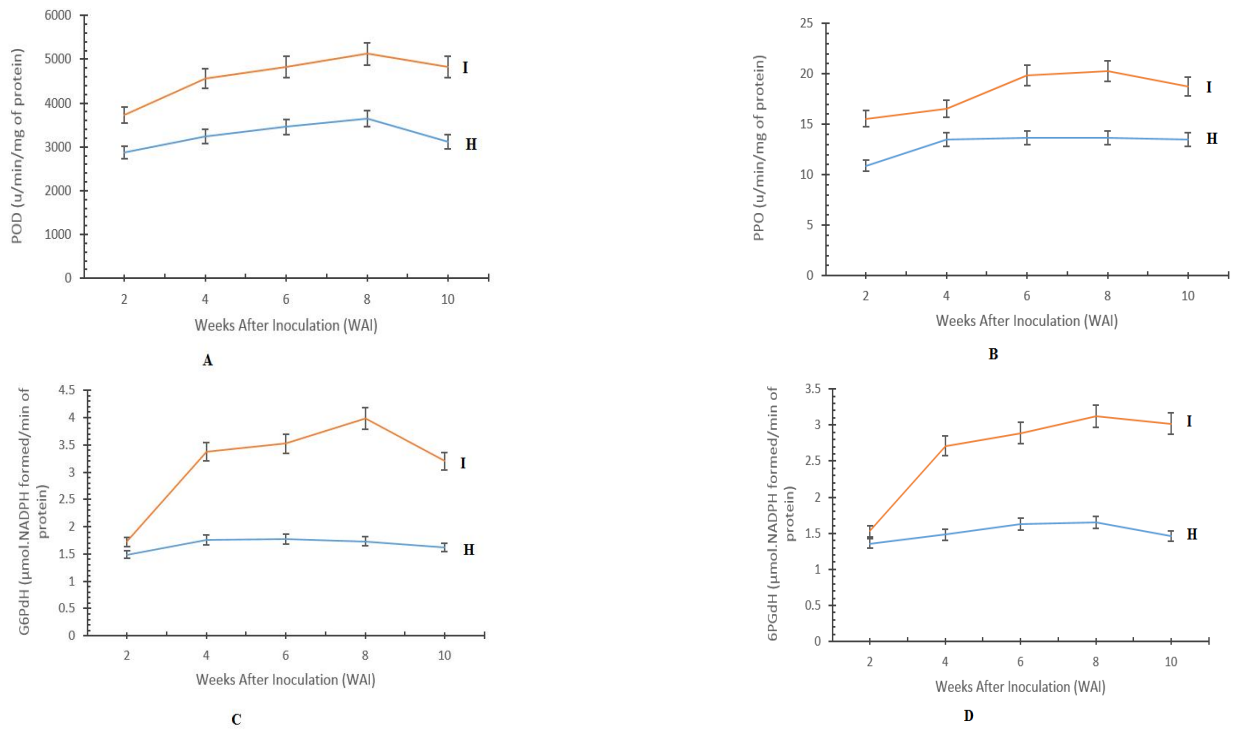

Fig. 3. Variation in $A=$ peroxidase (POD), $B=$ polyphenol oxidase (PPO), $C=$ glucose-6-phosphate dehydrogenase (6PGdH), D=6-phosphogluconic acid dehydrogenase (G6PdH) activity of Cucurbita moschata due to infection with a Nigerian Strain of Moroccan watermelon virus: Lagenaria breviflora isolate 
Leaf nitrogen content of infected plants was lower than that of healthy plants. Nitrogen is essential constituent of protein, enzymes, amino acids, nucleic acids and chlorophyll. Though nitrogen is a constituent of amino acids and enzymes which were increased due to MWMV, leaf nitrogen was significantly decreased in this study. Decrease in leaf nitrogen may be attributed to reduction in chlorophyll reported earlier by [5] since leaf $\mathrm{N}$ is an integral part of the chlorophyll molecule. Nitrogen is required for the synthesis of NADH, ATP, carbohydrates and lipids. Nitrogen is a determinant of growth and has the potential of improving the quality and yield of crops. Reduction in leaf $\mathrm{N}$ content may affect both growth and yield of inoculated plants. Nitrogen is an imperative factor in plant growth and governs a major constituent of chlorophyll. Moroccan watermelon mosaic virus altered leaf nitrogen content of $C$. moschata creating an imbalance in its content which resulted in variation affecting its physiology. The virus also caused decrease in relative water content. Variations in RWC in leaves of C. moschata due to MWMV is consistent with the report of lower water content in virus-infected leaves than in corresponding healthy tissues [15]. Relative water content in leaves of pepper plants infected by TMV decreased significantly [16]. Physiological processes of C. moschata are powered by water, and when water is lose, processes such as photosynthesis, respiration, transpiration, nutrients transport, buffering the plant against wide temperature fluctuations, are altered when leaves lose water. Reduction in relative water content decreased the efficiency of these processes. Photosynthesis is one of the physiological processes highly sensitive to water and a slight loss of water content in leaf decreased its efficiency. Relative water content is an indicator of water status of plants important in maintaining cell turgidity, structure and growth. Decrease in RWC in this study may be due to openings created for viral entry to leaves tissues during virus inoculation. Decrease in RWC was reported by [17] in Phaseolus vulgaris infected by Telfairia mosaic virus.

Antioxidative enzymes activity varied between inoculated and healthy plants with increase in POD, PPO, G6PdH and 6PGdH. Activity of oxidative stress enzymes (PPO and POD) were enhanced in inoculated plants. Higher POD and PPO activity in inoculated C. moschata plant and lower activity in the healthy revealed a clear variation in the activity of these oxidative stress enzymes. Inoculated plants displayed greater enzymes activity than their healthy counter parts. In other host-virus combination, [18] reported enhanced activities of peroxidase and polyphenol oxidase in viral infected leaves of sunflower plants than in the healthy [19] reported increased PPO levels in a plant when wounded or infected. Enhanced enzymes activity in this study could due to enzyme activation, high energy demand imposed on C. moschata by MWMV. Increase is suggestive of MWMV alterations in the activities of enzymes. Increase was a response to stress imposed on C. moschata by MWMV. Inoculated plants used energy faster than the healthy plants. Increase could be an indication of enzymes participation in scavenging reactive oxygen species. Enhanced enzymes activity could also be attributed to symptom severity which became obvious with prolonged period of development. These enzymes are very important in the physiological processes of plants. Peroxidase is an oxidoreductase enzyme widely distributed in plants and it control the peroxidative damage of cell walls of antioxidative enzyme system [20], they also control plant growth and development, construction, rigidification and lignifications of cell walls, protection of tissue from damage and infection caused by pathogenic organisms [21]. PPO is a nuclear encoded enzyme that catalyzes the oxygen dependent oxidation of phenols to quinones. Polyphenol oxidase is a tetramer that contains four atoms of copper per molecule and binding sites for two aromatic compounds and oxygen [22].

Enzymes activities of the oxidative pentose phosphate pathway (G6PdH, 6PGdH) were found to be higher in leaves of $C$. moschata inoculated with a Nigerian strain of MWMV: $L$. breviflora isolate when compared to the healthy. There was a clear variation between inoculated and $\mathrm{G} 6 \mathrm{PdH}, 6 \mathrm{PGdH}$ activity, with C. moschata plants containing the virus exhibiting greater enzymatic activity than the healthy plants. Similar reports of a massive accumulation of glucose-6phosphate in pepper-tobamovirus interaction are found [23]. [24] documented increased G6PDH activities in locally and systemically infected leaves of tobacco with Potato virus Y. Glucose-6phosphate dehydrogenase is an important enzyme of the OPPP responsible for NADPH production. The pathway metabolises glucose-6phosphate to ribose-5-phosphate, which is required for the de novo biosynthesis of purine and pyrimidine nucleotides of viral RNA. Glucose-6-phosphate dehydrogenase catalyzed the oxidation of Glucose-6-phosphate (G6P) to 6phosphogluconolactone concurrent with reducing 
NADP to NADPH. The product 6phosphogluconolactone is first converted to 6phosphogluconate phosphogluconolactonase and then decarboxylated by 6-phosphogluconate dehydrogenase, yielding another mole of NADPH and ribulose-5-phosphate. The NADPH (reducing power) generated by the OPPP is essential in sustaining the reductive biosynthesis of fatty acids, isoprenoids and aromatic amino acids in the dark and nitrogen assimilation useful to the plant. The OPPP is an alternative pathway for energy generation, alterations in $\mathrm{G} 6 \mathrm{PdH}$ enzymes activity of this pathway affects energy production. All enzymes activity decreased at later periods of growth and development. This decrease in enzymes activity is an indication of senescence which is characterized by a decline in physiological and metabolic activities. Variations in the components studied explain the poor growth reported of $C$. moschata infected with a Nigerian strain of MWMV [5].

\section{CONCLUSION}

The following conclusions are made from this study; that MWMV: L. breviflorus isolate caused significant variation in all amino acids with increase in MWMV infected C. moschata and decrease in healthy plant samples. Variation was found in peroxidase, polyphenol oxidase, glucose-6-phosphate dehydrogenase and 6phosphogluconic acid dehydrogenase activity with higher enzymes activity in inoculated $C$. moschata plants and lower activity in the healthy ones. Moroccan watermelon mosaic virus caused decrease in relative water content of inoculated plants compared to the healthy. The virus infection also led to significant variation in leaf nitrogen content with lower amount in inoculated plant and higher amount in healthy plants. These changes affected C. moschata growth and yield.

\section{ACKNOWLEDGEMENT}

The authors appreciate the department of Botany for the Botanical House used in the study

\section{COMPETING INTERESTS}

Authors have declared that no competing interests exist.

\section{REFERENCES}

1. Sastry KSZA. Management of virus and viroid diseases of crops in the tropics. (Springer: Dordrecht,); 2014.
2. Anderson PK, Cunningham AA, Patel NG, Morales FJ, Epstein PR, Daszak P. Emerging infectious diseases of plants: pathogen pollution, climate change and agrotechnology drivers. Trends Ecology and Evolution. 2004;19: 535-544. PMID: 16701319

DOI: 10.1016/j.tree.2004.07.021

3. Owolabi AT, Rabentein F, Ehrig F. A strain papaya ringspot virus naturally infecting cucumber (Cucumis sativus L.) in Calabar, South Eastern Nigeria. Nigeria Journal of Botany. 2008;21:97-108.

4. Owolabi AT, Rabenstein F, Ehrig F, Maiss Edgar M, Vetten HJ. Strains of moroccan watermelon mosaic virus Isolated from

Lagenaria breviflorus and Coccinia barteri in Calabar, Southeastern Nigeria. International Journal of Virology. 2012;8:258-270.

5. Mofunanya AAJ, Edu EA. Physiological and biochemical changes in cucurbita moschata duch. Ex. Poir Inoculated with a Nigerian Strain of Moroccan Watermelon Mosaic Virus (MWMV): Lagenaria breviflora Isolate. International Journal of Plant Pathology. 2015;6(2):3647. DOI: 10.3923/ijpp.2015.36.47

6. Spackman $\mathrm{DH}$, Stein $\mathrm{EH}$, Moore S. Automatic recording apparatue for use in the chromatography of amino acids. Analytical Chemistry. 1958;30:1191.

7. AOAC. Association of official analytical chemist, official method of analysis. $18^{\text {th }}$ edition. Washington: Washington D. C. Press; 2006.

8. Efeoglu B, et al. Physiological responses of three maize cultivars to drought stress and recovery. South African Journal of Botany. 2009;75:34-42.

9. Kahn V. Multiple effects of hydrogen peroxide on the activity of avocado polyphenol oxidase. Phytochemistry. 1983; 22: 2155-2159.

10. Gosling PG, Ross JD. Characterization of glucose-6-phosphate dehydrogenase and 6-phosphogluconic acid dehydrogenase from hazel cotyledons. Phytochemistry. 1979;18:1441-1445.

11. Soosaar JL, Burch-Smith TM, DineshKumar SP. Mechanisms of plant resistance to viruses. Nature ReviewsMicrobiology. 2005;3:789.798.

12. Guo L, Su Q, Yin J, Yang Z, Xie W, Wang $\mathrm{S}$, Wu Q, Cui $\mathrm{H}$, Zhang $\mathrm{Y}$. Amino acid utilization may explain why Bemisia 
tabaci $Q$ and $B$ differ in their performance on plants infected by the Tomato yellow leaf curl virus. Frontiers of Physiology; 2019.

DOI: 10:489. doi: .3389/fphys.2019.00489

13. Kang SS, Athar $M$, Cheema SS Physiological changes in cotton infected with Cotton leaf curl virus.Plant Disease Research. 2003; 9: 193.195.

14. Ashraf MY, Mahmood S, Sarwa G, Ashraf M, Naeem M, Zafar S. Physiological and biochemical changes in resistant and susceptible to Cotton leaf curl virus (CLCuV) cotton varieties at germination and early seedling stages: changes in lipase, oil content, protein and soluble sugars. International Journal of Biology and Biotechnology. 2004;1:217.222.

15. Hull R. Matthew's plant virology. London, Academic Press Incorporated; 2002.

16. Pazarlar S, Gumus M, Oztekin GB. The effects of tobacco mosaic virus infection on growth and physiological parameters in some pepper varieties (Capsicum annuum L.). Notulae Botanicae Horti Agrobotanici Cluj-Napoca. 2013;41(2):427-433.

17. Mofunanya AAJ, Effa EA, Ngele BA, Akomaye FA, Damian AO. Physiological interactions of Phaseolus vulgaris $\mathrm{L}$. with Telfairia mosaic virus. Acta Scientific Agriculture. 2021;5(6):102-108.

18. Papaiah S, Narasimha G. Peroxidase and polyphenol oxidase activities in healthy and viral infected sunflower (Helianthus annuus L.) leaves. Biotechnology An Indian Journal (BTAIJ), 2014;9(1):01-05.

19. Vanitha SC, Niranjana SR, Umesha S. Role of phenylalanine ammonia lyase and polyphenol oxidase in host resistance to bacterial wilt of tomato. Journal of Phytopathology. 2009;157:552-557.

20. Velikova V, Yardanov I, Edreva A. Oxidative stress and some antioxidant systems in acid raintreated beanplants.Plant $\quad$ Science. 2000 ;151(1):59.66.

21. Köksal E, Gülçin I. Purification and characterization of peroxidase from cauliflower (Brassica oleracea L. var. botrytis) Buds. Protein \& Peptide Letters. 2008;15(4):320-326.

22. MayerAlfred M. Polyphenol oxidases in plants and fungi:Going places? A review. Phytochemistry. 2006;67:2318.2331.

23. Rys $M$, Juhasz $C$, Surowka $E$, Janeczko $A$, Saja D, Tobias I, Skoczowski A, Barna B, Gullner G. Comparison of a compatible and an incompatible pepper-tobamovirus interaction by biochemical and noninvasive techniques: Chlorophyll a fluorescence, isothermal calorimetry and FT-Raman spectroscopy". Plant Physiology and Biochemistry. 2014;83:267-278.

24. Sindelaf $L$, Sindelarova M. Correction of viral genase activity with glucose-6phosphate dehydrogenase activity and host resistance. Planta. 2002;215: 869.

(c) 2021 Mofunanya et al.; This is an Open Access article distributed under the terms of the Creative Commons Attribution License (http://creativecommons.org/licenses/by/4.0), which permits unrestricted use, distribution, and reproduction in any medium, provided the original work is properly cited. 